International Journal of Environment, Agriculture and Biotechnology
Vol-6, Issue-1; Jan-Feb, 2021
JJEAB
Journal Home Page Available: https://ijeab.com/
Journal DOI: $10.22161 /$ ijeab

\title{
Investigation of Cowpea Variety and Storage Methods on Cowpea Beettle Infestation
}

\author{
Abodenyi, V.A. ${ }^{1}$; Adeosun, F. F. ${ }^{2}$; Samuel E. ${ }^{3}$; Gambo M. ${ }^{4}$ \\ ${ }^{1,4}$ Department of Agricultural and Bio- Environmental Engineering, Federal Polytechnic, Bauchi, Nigeria \\ ${ }^{2}$ Department of Nutrition and Dietetics, Federal Polytechnic, Bauchi, Nigeria \\ ${ }^{3}$ Food Science Technology Department, Federal Polytechnic, Bauchi, Nigeria
}

Received: 22 Oct 2020; Received in revised form: 25 Jan 2021; Accepted: 09 Feb 2021; Available online: 25 Feb 2021

(C)2021 The Author(s). Published by Infogain Publication. This is an open access article under the CC BY license

(https://creativecommons.org/licenses/by/4.0/).

\begin{abstract}
Investigation of effect of cowpea variety and storage methods on cowpea beetle (callosobuchus maculates) control was carried out with the main aim of providing suitable, safe and affordable methods of storing various varieties of cowpea devoid of infestation. Three varieties of cowpea which are White, Brown and Black varieties were used for this research. Various storage methods which include Plastics, Polyethylene, Hessian bags and Aluminum Bins of $10 \mathrm{~kg}$ capacity each was used in storing the cowpea. Twenty (20) cowpea beetle were introduced into the stored cowpea. Storage chemicals (phostoxine and Atelic dust) were introduced into the various stored cowpea at the same time of introducing the cowpea beetle. For each treatment there was a control and each was replicated three times. The storage was observed for a period of 90 days. The data generated were analyzed using MINITAB statistical software in analysis of variance (ANOVA).The result showed thatthe control treatment was generally less effective than the phostoxine and atelic dust at 90 days of storage and infestation of the cowpea. From tables 1, 2 and 3 all the storage methods were effective against the insect with significantly varying degree of efficiencies. Cowpea beetle mortality was significantly affected on the white variety more especially on the polyethylene storage and plastic containers with $95 \%$ and $100 \%$ mortality respectively. The Atelic showed mortality rate of $85 \%$ for both polyethylene and plastic containers while the control treatment has a value of $65 \%$ and $70 \%$ for both the polyethylene and plastic containers respectively. The Aluminum bin showed $80 \%$ mortality on phostoxine combination, $75 \%$ for the atelic and $50 \%$ for the control treatment.The mortality on the Black variety was significantly high after the 90 days infestation and storage for all the treatments and storage methods except for the Hessian bags that indicated $65 \%$ for phostoxine, $60 \%$ for atelic and $0 \%$ for the control treatment. The black variety showed less susceptibility to cowpea infestation when stored in polyethylene bag and airtight plastic container which had $100 \%$ mortality each.
\end{abstract}

Keyword-Cowpea, storage insect, varieties, infestation, mortality rate.

\section{INTRODUCTION}

Cowpea (vignaunguiculata) (L) walp is a warm weather crop that is well adapted to drier region of the tropics like Nigeria where other food legumes do not thrive well. It is one of the most economically and nutritionally important indigenous African grain legumes produced throughout the tropical and subtropical areas of the world (Golob et. al., 1999). Nigeria is its largest producer and consumer, accounting for about 45 percent of its world production (Degri, 2008), while Africa account for about $75 \%$ (Brternburg et.al., 1995). Cowpea seed pods are consumed in fresh form as green vegetables in some African countries, while the rest of the cowpea plant serves as a nutritious fodder for livestock and as a source of cash income when sold to farmers who use them as livestock 
feed. Cowpea seeds are also a rich source of minerals and obtains (Adeduntan et.al., 1998). Cowpea is sometimes called poor man meat or vegetable meat due to its high protein content. Cowpea grain contain $23.4 \%$ protein, $1.8 \%$ fat and $60.3 \%$ carbohydrates and a good source of vitamins and phosphorus (Adediran and Akinneye. 2004).

Despitethe great value of cowpea particularly in Nigeria, their availability and utilization have been impaired due to the seed damage by insect pest particularly the larvae of cowpea beetle (callosobuchusmaculatus) (Ofuya and Lale, 2001). Attack by insect pest species begins in the field and continues in storage causing substantial damage to store grain legumes as the pest rapidly increase. It has been reported that both quantitative and qualitative losses arising from physical, chemical and biological factors e. $g$ fungi, rodent, birds and insect occur during storage of grains (Emeasoret.al., 2007). Up to $100 \%$ Callusobruchus maculatusinfestation of cowpea can occur after three to six months storage (Maina, 2011).

Majority of farmers in Northern Nigeria and some other countries, including the Sudan, (Baribusta et. al, 2010)use local or indigenous storage facilities to forestall the menace of these insect pest they use storage insecticide where available and affordable like the banned and highly restricted lindens (gammalin A) and the acceptable are like Aluminum or Atelic EC for storing their legume grains against cowpea beets, termites, rats and disease pathogens (Degri,2007).

Some local plants have been studied to show they have effect against the activity of insect pest. They include; NeemAzadiracta (A.juss), Nicotine (Nicotiniaspp), pyrethrum chrysantheumceneraefolium), Rotenme (Derriselliptica) (C.P.F, 1987). Sadim apple "Locally name Usher" (Calotropisprocera (J.), Sesame (Sesamumindicum L.), Garlic (AllumSativum L.) and (Lantana Camara), (Mueller et. al., 1995). They were all found to lower fecundity per female and adult emergence (Singh et'al, 1996). But the availability and side effects of these are also a major concern to farmers. Hermetic storage technology has emerged as a potent alternative to other method of storage that protects commodities from insect and molds have been developed and applied and they abound in type and the PICS (Purdue Improved Cowpea Storage) which was founded by the Bill and Melinda Gates foundation, is just one of these. The goal of the project is to have $50 \%$ of farm-stored cowpea in hermetic storage without insecticide in west and central Africa (Murdock et al., 2003). This is still on-going.
From the forgoing, some methods of cowpea beetle control abound but not without so many limitations, they are not cheap and some are also hazardous to health. Application of storage chemicals are sometimes not done properly by the local farmer which can lead to food poisoning. Larger quantity of cowpea are sold off immediately after harvest by the local farmers because of lack of adequate storage methods and fear of infestation by cowpea beetles thereby selling at a lower price compared to cost of production. This makes the produce scarce after the period of harvest.

Thisresearch was carried out to investigate the effect of variety and storage methods on the control of the cowpea beetle Callosobruchus maculates (f) (coleopteran: Bruchide) on stored cowpea. Effect of various storage methods on the control of cowpea beetle was also investigated as well as the variety that responds well to the various storage methods.

\section{MATERIALS AND METHODS}

\subsection{Sample collection and preparation}

The following materials were used for the research, three varieties of cowpea: white variety (Kanannado), brown (Ife brown) and black (Akidi) variety. Insect pest cowpea beetle callosobruchusmaculates, was used as the insect pest, which were introduced to each treatment at same level. The seed scanner also known as dianophoscope was used to scan the cowpea seed in order to detect the effect of insect damage from each treatment. The storage methods used in this research are polyethylene (hermetic), storage bins which are made of aluminum, plastic containers and hessian bags. The storage chemicals that were used are phostoxin and atelic dust. These chemicals were chosen because they are mostly used by farmers in Bauchi State and in the wrong proportion and application. All the experimental materials were purchased from a local grain market in Bauchi State, Nigeria.

\subsection{Methods}

\subsubsection{Cleaning and Determination of Moisture content}

The purchased cowpea was cleaned to remove debris and all other foreign materials, this was done by hand picking, sorting and using winnower.Moisture content of each of the cowpea variety were determined using standard methods as used by Abodenyi et. al., 2018. This was to ensure that the sample were at the safe storage moisture content to minimize spoilage during storage period.

\subsubsection{Experimental procedures}


$2 \mathrm{~kg}$ of each variety were put in nine Polyethylene bags, the first three had phostoxine tablets introduced into it, and the next three had the atelic dust of $2 \mathrm{gm}$ introduced into them, the last three served as control with no treatment. Each of the storage samples had Twenty (20) cowpea beetles introduced into them. These methods were repeated for the Aluminum storage bins, the Plastic containers and the Hessian bags for each variety. After introduction of the storage pest, the samples were agitated for one minute each to allow even spread of the pest and storage chemical (Ebiamadon et al., 2011)

The experimental set up were laid out in a completely randomized design with three replicates kept in the postharvest laboratory of the department of agricultural bioenvironmental engineering of federal polytechnic, Bauchi, Nigeria at $31 \pm 2{ }^{\circ} \mathrm{C}$ and a relative humidity of $65 \pm 5$ for a period of 90 days

\subsection{Data Collection and Statistical Analysis}

The rate of infestation was determined for each variety after 90 days of infestation with the pest, the following data were collected.

1. Number of live and dead insects: this was counted manually and recorded from each treatment.
2. Percentage damage grains. The number of grains with holes and grains without roles in all the treatments in each variety: this was done by pouring the seed on a seed scanner to detect the damage seeds in each treatment, and manually counting the number of grains with holes and those without holes. The holes on the grain was used as an indicator of damage. Percentage grain damage was determined using the following formula.

$$
\begin{aligned}
& \text { percentage damage (\%) } \\
& =\frac{\text { number of damage grains }}{\text { total number of grain sampled }} \times 100
\end{aligned}
$$

Minitab statistical software was used in the analysis of variance (ANOVA) to determine the variation in results of all the experiments under the various independent variables and their interaction at $95 \%$ level. Descriptive statistics such as percentage was also used in presenting the data.

\section{RESULTS}

The results obtained are as presented in the tables below for the three varieties of cowpea

\begin{tabular}{|c|c|c|c|c|c|c|c|c|c|}
\hline & \multicolumn{9}{|c|}{ Treatments } \\
\hline \multirow{2}{*}{$\begin{array}{l}\text { Storage } \\
\text { methods }\end{array}$} & \multicolumn{3}{|c|}{ Phostoxine } & \multicolumn{3}{|l|}{ Atelic } & \multicolumn{3}{|l|}{ Control } \\
\hline & $\begin{array}{l}\text { Number } \\
\text { of live } \\
\text { beetles }\end{array}$ & $\begin{array}{l}\text { Number } \\
\text { of dead } \\
\text { beetles }\end{array}$ & $\begin{array}{l}\text { Percentage } \\
\text { mortality } \\
(\%)\end{array}$ & $\begin{array}{l}\text { Number } \\
\text { of live } \\
\text { beetles }\end{array}$ & $\begin{array}{l}\text { Number } \\
\text { of dead } \\
\text { beetles }\end{array}$ & $\begin{array}{l}\text { Percentage } \\
\text { mortality } \\
(\%)\end{array}$ & $\begin{array}{l}\text { Number } \\
\text { of live } \\
\text { beetles }\end{array}$ & $\begin{array}{l}\text { Number } \\
\text { of dead } \\
\text { beetles }\end{array}$ & $\begin{array}{l}\text { Percentage } \\
\text { mortality } \\
(\%)\end{array}$ \\
\hline $\begin{array}{l}\text { Polyethylene } \\
\text { Bags } \\
\text { Aluminum } \\
\text { Bins } \\
\text { Hessian Bags } \\
\text { Plastic } \\
\text { containers }\end{array}$ & $\begin{array}{l}4 \\
7 \\
0\end{array}$ & $\begin{array}{l}19 \\
16 \\
13 \\
20\end{array}$ & $\begin{array}{l}95 \\
\\
80 \\
65 \\
100\end{array}$ & $\begin{array}{l}3 \\
5 \\
10 \\
3\end{array}$ & $\begin{array}{l}17 \\
15 \\
10 \\
17\end{array}$ & $\begin{array}{l}85 \\
75 \\
50 \\
85\end{array}$ & $\begin{array}{l}7 \\
10 \\
20 \\
6\end{array}$ & $\begin{array}{l}13 \\
\\
10 \\
0 \\
14\end{array}$ & $\begin{array}{l}65 \\
50 \\
0 \\
70\end{array}$ \\
\hline
\end{tabular}

Table 1: Mean Effect of Cowpea Beetle Mortality on White Variety at 90 Days after Infestation

Table 2: Mean Effect of Cowpea Beetle Mortality on Brown Variety at 90 Days after Infestation 


\begin{tabular}{|c|c|c|c|c|c|c|c|c|c|}
\hline & \multicolumn{9}{|c|}{ Treatments } \\
\hline \multirow{2}{*}{$\begin{array}{l}\text { Storage } \\
\text { Methods }\end{array}$} & \multicolumn{3}{|c|}{ Phostoxine } & \multicolumn{3}{|l|}{ Atelic } & \multicolumn{3}{|l|}{ Control } \\
\hline & $\begin{array}{l}\text { Number } \\
\text { beetles }\end{array}$ & $\begin{array}{l}\text { Number } \\
\text { dead beet }\end{array}$ & $\begin{array}{l}\text { Percentage } \\
\text { mortality }(\%\end{array}$ & $\begin{array}{l}\text { Number } \\
\text { beetles }\end{array}$ & $\begin{array}{l}\text { Number } \\
\text { beetles }\end{array}$ & $\begin{array}{l}\text { Percentage } \\
\text { mortality (\% }\end{array}$ & $\begin{array}{l}\text { Number } \\
\text { beetles }\end{array}$ & $\begin{array}{l}\text { Number } \\
\text { beetles }\end{array}$ & $\begin{array}{l}\text { Percentage } \\
\text { mortality }(\%\end{array}$ \\
\hline $\begin{array}{l}\text { Polyethylene Bags } \\
\text { Aluminum Bins } \\
\text { Hessian Bags } \\
\text { Plastic containers }\end{array}$ & $\begin{array}{l}3 \\
6 \\
9 \\
3\end{array}$ & $\begin{array}{l}17 \\
14 \\
11 \\
17\end{array}$ & $\begin{array}{l}85 \\
70 \\
55 \\
85\end{array}$ & $\begin{array}{l}5 \\
6 \\
11 \\
4\end{array}$ & $\begin{array}{l}15 \\
14 \\
9 \\
16\end{array}$ & $\begin{array}{l}75 \\
70 \\
45 \\
80\end{array}$ & $\begin{array}{l}9 \\
15 \\
20 \\
9\end{array}$ & $\begin{array}{l}11 \\
5 \\
0 \\
11\end{array}$ & $\begin{array}{l}55 \\
25 \\
0 \\
55\end{array}$ \\
\hline
\end{tabular}

Table 3: Mean Effect of Cowpea Beetle Mortality on Black Variety at 90 Days after Infestation

\begin{tabular}{|c|c|c|c|c|c|c|c|c|c|}
\hline & \multicolumn{9}{|c|}{ Treatments } \\
\hline \multirow{2}{*}{$\begin{array}{l}\text { Storage } \\
\text { methods }\end{array}$} & \multicolumn{3}{|c|}{ Phostoxine } & \multicolumn{3}{|l|}{ Atelic } & \multicolumn{3}{|l|}{ Control } \\
\hline & $\begin{array}{l}\text { Number } \\
\text { of live } \\
\text { beetles }\end{array}$ & $\begin{array}{l}\text { Number } \\
\text { of dead } \\
\text { beetles }\end{array}$ & $\begin{array}{l}\text { Percentage } \\
\text { mortality } \\
(\%)\end{array}$ & $\begin{array}{l}\text { Number } \\
\text { of live } \\
\text { beetles }\end{array}$ & $\begin{array}{l}\text { Number } \\
\text { of dead } \\
\text { beetles }\end{array}$ & $\begin{array}{l}\text { Percentage } \\
\text { mortality } \\
(\%)\end{array}$ & $\begin{array}{l}\text { Number } \\
\text { of live } \\
\text { beetles }\end{array}$ & $\begin{array}{l}\text { Number } \\
\text { of dead } \\
\text { beetles }\end{array}$ & $\begin{array}{l}\text { Percentage } \\
\text { mortality } \\
(\%)\end{array}$ \\
\hline $\begin{array}{l}\text { Polyethylene } \\
\text { Bags } \\
\text { Aluminum } \\
\text { Bins } \\
\text { Hessian } \\
\text { Bags } \\
\text { Plastic } \\
\text { containers }\end{array}$ & $\begin{array}{l}0 \\
3 \\
7 \\
0\end{array}$ & $\begin{array}{l}20 \\
17 \\
13 \\
20\end{array}$ & $\begin{array}{l}100 \\
85 \\
65 \\
100\end{array}$ & $\begin{array}{l}1 \\
5 \\
8 \\
2\end{array}$ & $\begin{array}{l}19 \\
15 \\
12 \\
18\end{array}$ & $\begin{array}{l}95 \\
75 \\
60 \\
90\end{array}$ & $\begin{array}{l}7 \\
11 \\
20 \\
7\end{array}$ & $\begin{array}{l}13 \\
9 \\
0 \\
13\end{array}$ & $\begin{array}{l}65 \\
45 \\
0 \\
65\end{array}$ \\
\hline
\end{tabular}

Table 4: Mean Percentage (\%) of Damaged Cowpea at 90 Days after Infestation

\begin{tabular}{|c|c|c|c|c|c|c|c|c|c|}
\hline & \multicolumn{9}{|c|}{ Treatments } \\
\hline \multirow{2}{*}{$\begin{array}{l}\text { Storage } \\
\text { methods }\end{array}$} & \multicolumn{3}{|c|}{ White variety } & \multicolumn{3}{|c|}{ Brown variety } & \multicolumn{3}{|c|}{ Black variety } \\
\hline & Phostoxine & Atelic & Control & Phostoxine & Atelic & Control & Phostoxine & Atelic & Control \\
\hline $\begin{array}{l}\text { Polyethylene } \\
\text { Bags }\end{array}$ & 10 & 12 & 40 & 15 & 15 & 50 & 8 & 10 & 30 \\
\hline Aluminum & 40 & 50 & 60 & 50 & 55 & 60 & 30 & 40 & 55 \\
\hline Bins & 50 & 60 & 90 & 60 & 60 & 90 & 40 & 50 & 70 \\
\hline $\begin{array}{l}\text { Hessian Bags } \\
\text { Plastic } \\
\text { containers }\end{array}$ & 9 & 10 & 35 & 12 & 20 & 40 & 8 & 10 & 30 \\
\hline
\end{tabular}

\subsection{Discussion}

3.1.1 Cowpea Beetle Mortality on the various varieties of cowpea 
The control treatment was generally less effective than the phostoxine and atelic dust at 90 days of storage and infestation of the cowpea. From tables 1, 2 and 3 all the storage methods were effective against the insect with significantly varying degree of efficiencies. Cowpea beetle mortality was significantly affected on the white variety more especially on the polyethylene storage and plastic containers with $95 \%$ and $100 \%$ mortality respectively. The Atelic showed mortality rate of $85 \%$ for both polyethylene and plastic containers while the control treatment has a value of $65 \%$ and $70 \%$ for both the polyethylene and plastic containers respectively. The Aluminum bin showed $80 \%$ mortality on phostoxine combination, $75 \%$ for the atelic and $50 \%$ for the control treatment. The reduction of oxygen during the 90 days of storage after the infestation reduced the insect count drastically especially in the polyethylene bags and the plastic containers. This cannot be said of the Hessian bags because they are porous and allowed the thriving of the storage pest in all the treatments. This result agrees with the findings of (Ebiamadon et al., 2011) which researched the effectiveness of different botanical pesticides on control of C. maculatusat 30 and 90 days of infestation.

The mortality of cowpea beetle on the Brown variety, cowpea beetle mortality was significantly affected by the storage chemicals and the storage methods. Polyethylene together with phostoxine and plastic containers showed high mortality of $85 \%$. Atelic with polyethylene and plastic containers has mortality rate of $75 \%$ and $80 \%$ respectively. The control treatment indicated mortality of $55 \%$, this result agrees with PICS project (Villers, et al., 2008) which used the Hermetic storage methods by keeping away oxygen from the pest they were able to record $50 \%$ mortality. The Hessian bags showed $0 \%$ mortality for the control treatment.

Cowpea beetle mortality on the Black variety was significantly high after the 90 days infestation and storage for all the treatments and storage methods except for the Hessian bags that indicated $65 \%$ for phostoxine, $60 \%$ for atelic and $0 \%$ for the control treatment.

\subsubsection{Cowpea Damage at 90 Days after Infestation}

Table four shows the degree of damage on the three varieties of cowpea after 90 days of infestation. The Hessian bag recorded the highest percentage of damage on all the storage methods and treatments for the three varieties. This can be attributed to the fact that the Hessian bag is porous that allowed intake of oxygen that allowed the survival of the storage pest. The White and black variety recorded less damage form the beetle from all the storage methods and treatments, this could be as a result of the high protein content of Brown beans, storage pest tends to feast more on highly protein food (AOAC, 2010).

\section{CONCLUSION}

From the above results, it can be concluded that the black variety is less susceptible to cowpea infestation when stored in a polyethylene bag as well as in an airtight plastic container.

\section{FUNDING}

Victoria Ada Abodenyi is thanking Tertiary Education Trust Fund (TETFUND) Nigeria for sponsoring this research work and the staff and management of The Federal Polytechnic, Bauchi, Nigeria for this opportunity.

\section{REFERENCES}

[1] Adediran, C.O and J.O Akinneye, (2004). Biological activity of tree marigold, Tithoniadiversifoliaon cowpea seed bruchid, Collasobruchus maculates (Coleoptera: Bruchidae). Animal of Applied Biology, 14: 185-189.

[2] Adeduntan, S.A., and Ofuya, T.I (1998). Evaluation of seeds of selected varieties of cowpea, Vigna unguiculata (L.) Walp. For susceptibility to Callosobruchusmaculates (F.) (Coleopera: Bruchidae). Applied Trop. Agric., 3:45-51.

[3] AOAC (2002) Association of Official Analytical Chemists.

[4] Bitternburg, H. (1995). Farmers' Perception of Crop Pests and Pest Control Practices in Rain Fed Cowpea Cropping System in Kano, Nigeria. International Journal of Pest Management (41(4): 195-200.

[5] Baribusta, D., Lowerberg - Debeor, J., Murdock, L., Moussa, B. (2010). Profitable chemically free cowpea storage technology for small holder farmers in Africa: opportunity and challenges. $10^{\text {th }}$ international working Conference on stored product protection. pp. 1046-1053.

[6] Degri, M.M. (2008). Safe use handling of pesticides in Agriculture. A paper presented at a training workshop organized by NFDP II for fardama user group (FUGs), facilitators and desk office Fadama II Project Gombe state at women development centre, Gombe $4^{\text {th }}-5^{\text {th }} 200819$ pp.

[7] Degri, M.M. (2007). Storage pests of cereals and legumes. A paper presented at a training workshop organized by Fadama Development Project (NFDP II) for Bajoga East/ AshakaFadama Community Association (FCA) at Fanakage L.G.A secretariat, Bajoga, $27^{\text {th }}-28^{\text {th }}$ October, 200714 pp. 
[8] C.P.F. (1987). Insect Pest and pest harvest problems in the tropics. Insect Science and its application 8:673-676.

[9] Ebiamadon Andi Brisibe, Sophia ElohoAdugbo, UduakEkanem, FraidehBrisibe and Glyn Mara Figueira (2011). Controlling bruchid pests of stored cowpea seeds with dried leaves of Artemisia annua and two other common botanicals. African Journal of Biotechnology Vol. 10(47), pp. 9586-9592, 24 August, 2011

[10] Emeasor, K.C., Emosairue, S.O. and Ogbuji, R.O. (2007). Preliminary evaluation of the efficacy of mixed powders of piperguineense (Schum and Thonn) and Thevetia Peruviana (Person) against Collosbruchus Maculatus (F.) (Coleoptera: Bruchifae) Nigeria Journal of Entomology, 24:114 - 118.

[11] Golob, P., Moss, C., Devereau, A., Goodland, A.D., Andan, F.H., Atarigya, J. and Tran, B.M.D. (1999). Improvements in the Storage and Marketing Quality of Grain Legumes: Final Technical Report, NRI Report 2417, Project R 6503. Natural Resources Institute University of Greenwich Chatham Maritime Kent UK. 51pp.

[12] Maina, Y. T. (2011). Effects of Different Levels of Infestation and Storage Durations on The Development of Callosobruchusmaculates (Fabricius.) In Stored Cowpea Vigna Unguiculata (L.) Walpers. Production AgricultureandTechnology, 7 (1): 49-54.

[13] Mueller, D.K. (1995) Low concentration phosphine fumigation method us patient 5:403 - 597 .

[14] Murdock, L.L., Ntooukau, G., Kitch, L. and Shade, R.E., (2003). Preservation of cowpea grain sub- sahara Africa Bean/cowpea contributions. Field crop. Res. 82, 169 -178.

[15] Ofuya, T.I., and Lale, (2001). Pests of stored cereals and pulses in Nigeria Biology ecology and control. Mole publishers, Akure, Nigeria, 174pp.

[16] Villers, P., Navarro, S., Bruin, T. (2008). Development of Hermetic Storage Technology in Sealed Flexile Storage Structure. Citation for Controlled Atmosphere and fumigation (CAF) Conference in Chendu, China, September, 2008 Session. 